Article

\title{
Improving Anaerobic Digestion of Sewage Sludge by Hydrogen Addition: Analysis of Microbial Populations and Process Performance
}

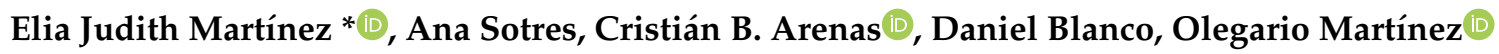 \\ and Xiomar Gómez *(i)
}

Chemical and Environmental Bioprocess Engineering Group, Natural Resources Institute (IRENA), University of Leon, Av. de Portugal 41, 24009 Leon, Spain; asotf@unileon.es (A.S.); cares@unileon.es (C.B.A.); info@bioenergiaydt.com (D.B.); omarm@unileon.es (O.M.)

* Correspondence: ejmartr@unileon.es (E.J.M.); xagomb@unileon.es (X.G.)

Received: 5 March 2019; Accepted: 26 March 2019; Published: 30 March 2019

check for updates

\begin{abstract}
The effect of hydrogen pulse addition on digestion performance of sewage sludge was evaluated as a means for studying the increase in efficiency of methane production. Microbial communities were also evaluated to get an insight of the changes caused by the operational modifications of the digester. An energy evaluation of this alternative was performed considering the theoretical process of coupling bioelectrochemical systems (BES) for the treatment of wastewater along with hydrogen production and the subsequent anaerobic digestion. The addition of hydrogen to sewage sludge digestion resulted in an increase of $12 \%$ in biogas production over the control (1353 $\mathrm{mL} \mathrm{CH}_{4} \mathrm{~d}^{-1}$ at an injection flow rate of $1938 \mathrm{~mL} \mathrm{H}_{2} \mathrm{~d}^{-1}$ ). The liquid phase of the sludge reactor and the $\mathrm{H}_{2}$ supplemented one did not show significant differences, thus indicating that the application of hydrogen as the co-substrate was not detrimental. High-throughput sequencing analysis showed slight changes in archaeal relative abundance after hydrogen addition, whereas eubacterial community structure and composition revealed noteworthy shifts. The mass and energy balance indicated that the amount of hydrogen obtained from a hypothetical BES can be assimilated in the sludge digester, improving biogas production, but this configuration was not capable of covering all energy needs under the proposed scenario.
\end{abstract}

Keywords: sludge digestion; hydrogen addition; microbial community analysis; energy performance

\section{Introduction}

The most widely used technology for the treatment of municipal wastewaters is based on an activated-sludge process in spite of its high energy cost (up to $\sim 75 \%$ of the total energy costs of a plant) [1]. The number of wastewater plants has increased due to rapid urbanisation and it has brought along a significant increase of the volume of sludge needing adequate management [2].

This sewage sludge is characterised by high organic content needing to be properly disposed of. However stringent regulations and pollution problems associated with uncontrolled decomposition of organic matter and nutrient run off make it imperative to search for feasible treatment alternatives. Traditionally, sludge is treated by extended aeration when the size of a wastewater treatment plant (WWTP) is too small, thus making it unfeasible to install an anaerobic digester. For large plants, the stabilisation via anaerobic digestion is the preferred choice. The production of biogas and subsequent conversion into electrical energy by means of a combined heat and power (CHP) unit makes this process a desirable option for reducing the external energy demand of a WWTP. Nevertheless, some disadvantages are associated with the digestion of waste activated sludge (WAS) such as low methane 
production due to its low biodegradability. Therefore, different pre-treatment technologies have been developed with the aim of increasing the biogas yield, accelerating the degradation rate, and producing a biosolid that is safer and easier to handle and dispose of [3-5]. However, the application of pre-treatments may bring along an increase in the energy demand of the global process [6].

The enhancement of anaerobic digestion (AD) can also be achieved by the addition of a co-substrate. Several co-substrates have been evaluated in an attempt to increase the organic loading of a reactor and to balance nutrients [7-9]. AD is a complex process where the conversion of organic matter takes place by means of microorganisms in the absence of oxygen. The breakdown of organic matter can be summarised in four major stages: hydrolysis, acidogenesis, acetogenesis and methanogenesis, which are carried out by a consortium of mutually dependent microorganisms including hydrolytic-fermentative bacteria, proton-reducing acetogenic bacteria, hydrogenotrophic methanogens and acetoclastic methanogens [10]. The development of AD is strongly related to the structure of the microbial communities present in the reactor in addition to the operating conditions applied [11]. Therefore, introduction of hydrogen gas as a co-substrate into an anaerobic digester may cause changes in microbial communities, and these changes may in turn result in modifications of the main degradation pathways.

Methanogens are strictly anaerobic archaea grouped into acetoclastic and hydrogenotrophic methanogens. The common substrates of hydrogenotrophic methanogens are $\mathrm{H}_{2}, \mathrm{CO}_{2}$ and formate, whereas acetate is the main substrate for acetoclastic methanogens producing methane via acidogenesis and acetogenesis although a few other compounds like methanol, ethanol and pyruvate can also be utilised [12,13]. Due to the restricted metabolism of methanogens, the organic compounds present in sewage sludge (SS) are degraded in an anaerobic environment by association with fermenting and acetogenic bacteria. This syntrophic relationship is sustained by interspecies hydrogen transfer. Hydrogen, which is consumed by hydrogenotrophic methanogens, is a key intermediary in the anaerobic degradation of organic matter. Hydrogen levels and interspecies hydrogen transfer optimise the metabolism of the entire microbial community present in biogas-producing consortia [14,15].

There exist several studies on the application of hydrogen with the aim of improving biogas production. One approach is to promote the production of hydrogen and its transfer between syntrophic methanogenic partners via bioaugmentation by the introduction of a $\mathrm{H}_{2}$-producing bacterium into the anaerobic consortia $[15,16]$, and the other approach involves injection of hydrogen gas into the reactor. Although utilisation of hydrogen by microorganisms is hindered by mass transfer limitations, several studies have shown that its application in pulses significantly increases methane production $(\sim 30 \%)$ by the action of hydrogenotrophic methanogens [17-20].

The replacement of the activated-sludge process by a bioelectrochemical system (BES) has been proposed by several authors as a means for reducing the high energy demand of wastewater treatment systems [21,22]. The use of microbial fuel cells allows for the net production of energy that comes from the conversion of the organic material contained in wastewater. However, there is a limited understanding about the capacity of these systems for converting organic matter contained in wastewater and turn it into energy to attain a net positive energy balance [23]. On the other hand, in microbial electrolysis cells (MECs), organic matter of the liquid stream is transformed by microorganisms with application of small voltage resulting in production of hydrogen at the cathode [24]. Due to the urgent need for reducing the large amount of energy necessary for the treatment of municipal wastewater, the key for attaining energy self-sufficiency seems to be closely related to reducing aeration requirements and increasing the biogas yield.

In the present study, a sludge digester supplemented with hydrogen was assessed to evaluate performance of the reactor and the effect on the energy balance of a WWTP when a BES serves as an alternative for the treatment of wastewaters. The aim of the present work was to study the microbiological changes taking place during digestion of sewage sludge along with the effect on biogas productivity, digestion performance and energy demand of the whole combined configuration. 


\section{Materials and Methods}

\subsection{Substrates}

Primary sludge (PS), waste activated sludge (WAS) and digested sludge from the anaerobic reactor were obtained from the WWTP of León (Spain). The plant has an anaerobic digester operating under a mesophilic regimen. The digested sludge was used as inoculum. Sewage sludge used as substrate was a mixture of PS and WAS at a 30:70 (v/v) ratio. The selection of this ratio was based on the volumetric proportions of sludge flow produced in the WWTP. The chemical characteristics of these materials are presented in Table 1. Some additional data are provided in the Supplementary Materials.

Table 1. Substrate characterisation.

\begin{tabular}{|c|c|c|c|c|}
\hline Chemical Parameters & Inoculum & PS & WAS & Mixture \\
\hline Total solids $\left(\mathrm{g} \mathrm{kg}^{-1}\right)$ & $30.8 \pm 0.9$ & $31.5 \pm 0.9$ & $27.0 \pm 0.8$ & $28.2 \pm 0.7$ \\
\hline Volatile solids $\left(\mathrm{g} \mathrm{kg}^{-1}\right)$ & $18.2 \pm 0.5$ & $26.4 \pm 0.8$ & $21.4 \pm 0.6$ & $22.9 \pm 0.7$ \\
\hline Total soluble organic carbon $\left(\mathrm{g} \mathrm{L}^{-1}\right)$ & $2.97 \pm 0.14$ & $3.45 \pm 0.17$ & $1.06 \pm 0.05$ & $1.41 \pm 0.08$ \\
\hline Ammonia $\left(\mathrm{mg} \mathrm{L}^{-1}\right)$ & $742 \pm 29$ & $968 \pm 38$ & $487 \pm 19$ & $655 \pm 21$ \\
\hline $\mathrm{pH}$ & $7.10 \pm 0.01$ & $5.20 \pm 0.01$ & $6.13 \pm 0.01$ & $5.62 \pm 0.01$ \\
\hline Chemical oxygen demand $\left(\mathrm{mg} \mathrm{L}^{-1}\right)$ & $2178 \pm 109$ & $3172 \pm 159$ & $2569 \pm 128$ & $2744 \pm 137$ \\
\hline Organic matter $(\%)^{*}$ & $42.43 \pm 0.14$ & $53.85 \pm 1.06$ & $59.21 \pm 0.09$ & $56.40 \pm 0.49$ \\
\hline Kjeldahl nitrogen $(\%)^{*}$ & $4.87 \pm 0.19$ & $5.10 \pm 0.15$ & $9.43 \pm 0.28$ & $7.86 \pm 0.23$ \\
\hline $\mathrm{C} / \mathrm{N}$ ratio & 5.04 & 6.16 & 3.65 & 4.21 \\
\hline Acetic acid $\left(\mathrm{mg} \mathrm{L}^{-1}\right)$ & n.d. & $2279 \pm 114$ & $397 \pm 16$ & $1007 \pm 40$ \\
\hline Propionic acid $\left(\mathrm{mg} \mathrm{L}^{-1}\right)$ & n.d. & $1581 \pm 79$ & $228 \pm 14$ & $682 \pm 26$ \\
\hline Isobutyric acid (mg L $\left.{ }^{-1}\right)$ & n.d. & $199 \pm 10$ & $49.42 \pm 2.52$ & $89.33 \pm 4.46$ \\
\hline Butyric acid $\left(\mathrm{mg} \mathrm{L}^{-1}\right)$ & n.d. & $1471 \pm 59$ & $51.71 \pm 1.55$ & $517 \pm 16$ \\
\hline Isovaleric acid $\left(\mathrm{mg} \mathrm{L}^{-1}\right)$ & n.d. & $208 \pm 26$ & $51.23 \pm 1.20$ & $132 \pm 21$ \\
\hline Valeric acid $\left(\mathrm{mg} \mathrm{L}^{-1}\right)$ & n.d. & $449 \pm 13$ & $44.70 \pm 1.10$ & $209 \pm 15$ \\
\hline Volatile fatty acids, total $\left(\mathrm{mg} \mathrm{L}^{-1}\right)$ & n.d. & $5083 \pm 254$ & $658 \pm 18$ & $2639 \pm 132$ \\
\hline Cadmium $\left(\mathrm{mg} \mathrm{kg}^{-1}\right)$ & $0.030 \pm 0.001$ & $0.020 \pm 0.001$ & $0.030 \pm 0.001$ & $0.020 \pm 0.001$ \\
\hline Chromium $\left(\mathrm{mg} \mathrm{kg}^{-1}\right)$ & $1.10 \pm 0.01$ & $0.68 \pm 0.01$ & $0.73 \pm 0.01$ & $0.75 \pm 0.01$ \\
\hline Copper $\left(\mathrm{mg} \mathrm{kg}^{-1}\right)$ & $3.97 \pm 0.20$ & $2.67 \pm 0.13$ & $3.75 \pm 0.15$ & $3.32 \pm 0.12$ \\
\hline Phosphorus (mg kg-1) & $447 \pm 22$ & $336 \pm 17$ & $862 \pm 43$ & $681 \pm 34$ \\
\hline Nickel $\left(\mathrm{mg} \mathrm{kg}^{-1}\right)$ & $0.66 \pm 0.01$ & $0.37 \pm 0.01$ & $0.34 \pm 0.01$ & $0.33 \pm 0.01$ \\
\hline Lead $\left(\mathrm{mg} \mathrm{kg}^{-1}\right)$ & $2.47 \pm 0.12$ & $1.87 \pm 0.10$ & $1.23 \pm 0.10$ & $1.39 \pm 0.11$ \\
\hline Zinc $\left(\mathrm{mg} \mathrm{kg}^{-1}\right)$ & $32.55 \pm 0.98$ & $18.17 \pm 0.75$ & $22.03 \pm 0.83$ & $19.61 \pm 0.75$ \\
\hline
\end{tabular}

*\% expressed on a dry matter basis, n.d.: not detected.

\subsection{Experimental Set-Up: Semi-Continuous Digestion}

Semi-continuous reactors were evaluated using sewage sludge as substrate. An initial adaptation period of $28 \mathrm{~d}$ was established with a hydraulic retention time (HRT) of $25 \mathrm{~d}$. The operating performance of the reactor was subsequently evaluated at an HRT of $21 \mathrm{~d}$ for a $106 \mathrm{~d}$ period. The experiments were carried out in completely mixed reactors (working volume of $3 \mathrm{~L}$ under mesophilic conditions: $37 \pm 1^{\circ} \mathrm{C}$ ). Reactors were manually fed once a day and were equipped with mechanical agitators and outer-jackets to circulate heating water and sampling ports for the withdrawal of liquid samples and gas collection. Feeding was manually performed once a day and the samples were taken three times a week before feeding the reactors and after complete homogenisation. Daily gas production was measured using a reversible liquid displacement device with a wet-tip counter

The reactors were labelled as control reactor (CR) treated sludge as a sole substrate and the reactor supplemented with hydrogen pulses was designated as HR and also utilised sludge as a carbon source. The addition of hydrogen was carried out daily through a ceramic diffuser at the bottom of the reactor for $6 \mathrm{~h}$. The flow rate was adjusted in the range between 0.5 and $2 \mathrm{~L} \mathrm{H}_{2} \mathrm{~L} \mathrm{Reactor}^{-1} \mathrm{~d}^{-1}$ using a flow meter model FR2A12BVBN from KI instruments.

The utilisation of hydrogen by microorganisms was calculated based on the difference between the volume of biogas measured from the HR and the measurements of methane and hydrogen gas from the CR and HR. It was assumed that all hydrogen measured in the exit gas stream corresponds to the 
excess amount injected that was not transferred into the liquid phase. The amount of hydrogen derived from the metabolism of sludge was disregarded because of the large injected amount as hydrogen flow.

Microbial analysis was performed on samples taken from these reactors on day 28, representing the end of the adaptation period, and on days 59 and 105, with these two latter samples being representative of the performance of the digester when hydrogen supplementation was fully implemented.

\subsection{Analytical Techniques}

Total and volatile solids (TS, VS), $\mathrm{pH}$, ammonia and alkalinity were measured in accordance with APHA Standard Methods [25]. Nitrogen concentration was measured by the Kjeldahl method. Organic matter was analysed in accordance with the Walkley-Black method [26]. An Analytik Jena Multi N/C_3100 systems by thermocatalytic oxidation was used for the quantification of total organic carbon (TOC) and total nitrogen (TN). The analysis of metals was carried out on a PerkinElmer Optima 2000 DV inductively coupled plasma atomic emission spectrometer as described by Fierro et al. [27].

Biogas composition was daily monitored by means of a gas chromatograph (Varian CP3800 GC) equipped with a thermal conductivity detector. A packed column (HayeSep Q 80/100; $4 \mathrm{~m}$ ) along with a molecular-sieve column $(1 \mathrm{~m})$ was used to separate $\mathrm{CH}_{4}, \mathrm{CO}_{2}, \mathrm{~N}_{2}, \mathrm{H}_{2}$ and $\mathrm{O}_{2}$. The carrier gas was helium, and the columns were operated under a pressure of $331 \mathrm{kPa}$ and a temperature of $50{ }^{\circ} \mathrm{C}$. Volatile fatty acids (VFAs) were measured using a gas chromatograph and a flame ionisation detector (FID) equipped with a Nukol capillary column $(30 \mathrm{~m} \times 0.25 \mathrm{~mm} \times 0.25 \mu \mathrm{m})$ from Supelco. The carrier gas was helium. The injector and detector temperatures were 220 and $250^{\circ} \mathrm{C}$, respectively. The oven temperature was set to $150{ }^{\circ} \mathrm{C}$ for $3 \mathrm{~min}$ and was increased to $180^{\circ} \mathrm{C}$ with a ramp of $10^{\circ} \mathrm{C} \mathrm{min}^{-1}$. The detection limit for VFA analysis was $5.0 \mathrm{mg} \mathrm{L}^{-1}$. The system was calibrated with a mixture of standard volatile acids from Supelco (for the analysis of fatty acids C2 to C7). Samples were pre-centrifuged $(10 \mathrm{~min}, 3500 \times g)$ and the supernatant was passed through $0.45 \mu \mathrm{m}$ cellulose filters.

\subsection{High-Throughput Sequencing of Massive $16 S$ rRNA Gene Libraries}

DNA was extracted with the PowerSoil ${ }^{\circledR}$ DNA Isolation Kit (MoBio Laboratories Inc., Carlsbad, CA, USA) from substrates (SS), inoculum, and digested sludge obtained from reactors as described in the experimental set-up sub-section. All PCRs were carried out on a Mastercycler (Eppendorf, Hamburg, Germany), and PCR samples were checked for size of the product on a $1 \%$ agarose gel. The entire DNA extract was subjected to high-throughput sequencing of the 16S rRNA gene based massive libraries for total eubacterial and archaeal populations. Each sample was amplified with the primer set 27F mod (5'-AGRGTTTGATCMTGGCTCAG-3') with 519R modBio (5'-GTNTTACNGCGGCKGCTG-3') [28] and Arch 349F (5'-GYGCASCAGKCGMGAAW-3') with Arch 806R (5'-GGACTACVSGGGTATCTAAT-3') [29] for the eubacterial and archaeal population, respectively. The obtained DNA reads were compiled into FASTq files for further bioinformatics processing following the MR DNA Research Lab instructions (http://www.mrdnalab.com/). Operational taxonomic units (OTUs) were then taxonomically classified using the Ribosomal Database Project (https://rdp.cme.msu.edu/).

\subsection{Energy Balance}

Based on results obtained from the digester working under different regimens of hydrogen injection, a mass and energy balance was determined to evaluate the benefits of integrating a MEC system instead of a conventional WAS process. The hydrogen produced by the BES was assumed to be injected into the anaerobic digester. Two scenarios were evaluated. The first one takes into consideration a conventional WWTP for 150,000 equivalent inhabitants (Eq. Inh.), while the second scenario assumes installation of a BES for the treatment of wastewater. Under this latter scenario, the hydrogen produced from the water line was transformed into methane in the digester. Calculation of energy production was based on hydrogen conversion values obtained from the experimental set-up. 
The base scenario regarded the water line as composed of a conventional WAS system and an air flotation unit for concentrating the secondary sludge. The sludge line consisted of the primary settler and the gravity thickener where the primary sludge was concentrated and posteriorly mixed with the secondary sludge. The anaerobic digester treated this mixture at an HRT of $20 \mathrm{~d}$.

\section{Results and Discussion}

\subsection{Analysis of Methane Production}

The parameters obtained from the anaerobic digestion of SS are summarised in Table 2. A remarkable increase in biogas production and a slight increase in methane concentration were achieved in the HR compared with the CR. Figure 1 shows the biogas production and composition of both systems under the semi-continuous regimen. An increase in the average biogas production was observed with the increase in the injection of hydrogen, indicating the capacity of the consortium for hydrogen utilisation. The maximum gas production of $1353 \mathrm{~mL} \mathrm{CH}_{4} \mathrm{~d}^{-1}$ was reached at an injection rate of $1938 \mathrm{~mL} \mathrm{H}_{2} \mathrm{~d}^{-1}$ with injection velocity $5.38 \mathrm{~mL} \mathrm{~min}^{-1}$ (period V). This value represents an improvement of $12 \%$ over the control. The utilisation of hydrogen by microorganisms at the different injection flow rates tested was not greater than $75 \%$, and the excess injected hydrogen became a part of the exiting biogas from the reactor (see biogas composition in Figure 1d,e).

Despite the significant improvement achieved in biogas production, this was not directly related to a significant increase in methane concentration (methane content in biogas was $\sim 60 \%-68 \%$ ) for the HR system. Studies by Luo and Angelidaki [18] of gas upgrading (in a thermophilic anaerobic reactor treating sludge) revealed greater content of $\mathrm{CH}_{4}(\sim 90 \%)$ in biogas when digested manure served as an inoculum among others and gas injection rates were between 3 and $24 \mathrm{~L} \mathrm{~L}^{-1}$ reactor $\mathrm{d}^{-1}$.

Table 2. Parameters of the digestion process.

\begin{tabular}{|c|c|c|c|c|c|c|c|c|}
\hline \multicolumn{3}{|c|}{ Control Reactor (CR) } & \multicolumn{6}{|c|}{ Hydrogen Reactor (HR) } \\
\hline Periods & $\begin{array}{c}\text { Adaptation } \\
\text { I }\end{array}$ & $\begin{array}{l}\text { Evaluation } \\
\text { (II-VI) }\end{array}$ & $\begin{array}{c}\text { Adaptation } \\
\text { I }\end{array}$ & II & III & $\begin{array}{c}\text { Evaluation } \\
\text { IV }\end{array}$ & $\mathbf{v}$ & VI \\
\hline Days evaluated & 28 & 105 & 28 & 11 & 27 & 20 & 24 & 23 \\
\hline OLR $\left([\mathrm{kg} \mathrm{VS}] \mathrm{L}^{-1} \mathrm{~d}^{-1}\right)$ & 0.99 & 1.08 & 0.99 & 1.14 & 1.04 & 1.1 & 0.97 & 1.17 \\
\hline $\mathrm{H}_{2}$ injection flow $\left(\mathrm{mL} \mathrm{d}^{-1}\right)$ & n.a. & n.a. & 0 & $780 \pm 269$ & $1125 \pm 207$ & $1588 \pm 260$ & $1938 \pm 330$ & $2004 \pm 350$ \\
\hline $\mathrm{H}_{2}$ Transported $\left(\mathrm{mL} \mathrm{d}^{-1}\right)$ & n.a. & n.a. & 0 & $617 \pm 291$ & $683 \pm 286$ & $709 \pm 166$ & $768 \pm 196$ & $750 \pm 206$ \\
\hline Volatile solids $\left(\mathrm{g} \mathrm{L}^{-1}\right)$ & $13.2 \pm 0.1$ & 10.52 & $13.6 \pm 0.1$ & $12.5 \pm 0.1$ & $8.2 \pm 0.1$ & $8.0 \pm 0.1$ & $8.1 \pm 0.1$ & $8.3 \pm 0.1$ \\
\hline $\mathrm{CH}_{4}\left(\mathrm{~mL} \mathrm{~d}^{-1}\right)$ & $857 \pm 25$ & $1113.23 \pm 55$ & $927 \pm 15$ & $1030 \pm 20$ & $1318 \pm 26$ & $1266 \pm 25$ & $1353 \pm 27$ & $1222 \pm 24$ \\
\hline Biogas without $\mathrm{H}_{2}\left(\mathrm{~mL} \mathrm{~d}^{-1}\right)$ & - & - & $1524 \pm 338$ & $1523 \pm 237$ & $1955 \pm 258$ & $1904 \pm 270$ & $1976 \pm 271$ & $1842 \pm 450$ \\
\hline$\% \mathrm{CH}_{4}$ & $59.79 \pm 1.43$ & 63.18 & $60.86 \pm 1.71$ & $59.39 \pm 3.19$ & $55.81 \pm 6.91$ & $44.41 \pm 8.07$ & $41.61 \pm 6.50$ & $41.78 \pm 6.5$ \\
\hline$\% \mathrm{CH}_{4}$ normalised ${ }^{*}$ & - & - & $60.86 \pm 1.71$ & $67.67 \pm 1.63$ & $67.42 \pm 5.52$ & $66.51 \pm 3.60$ & $68.51 \pm 2.70$ & $66.39 \pm 4.5$ \\
\hline
\end{tabular}

${ }^{*}$ Normalisation without hydrogen (methane + carbon dioxide), HRT: hydraulic retention time, OLR: organic loading rate, SMP: specific methane production. 

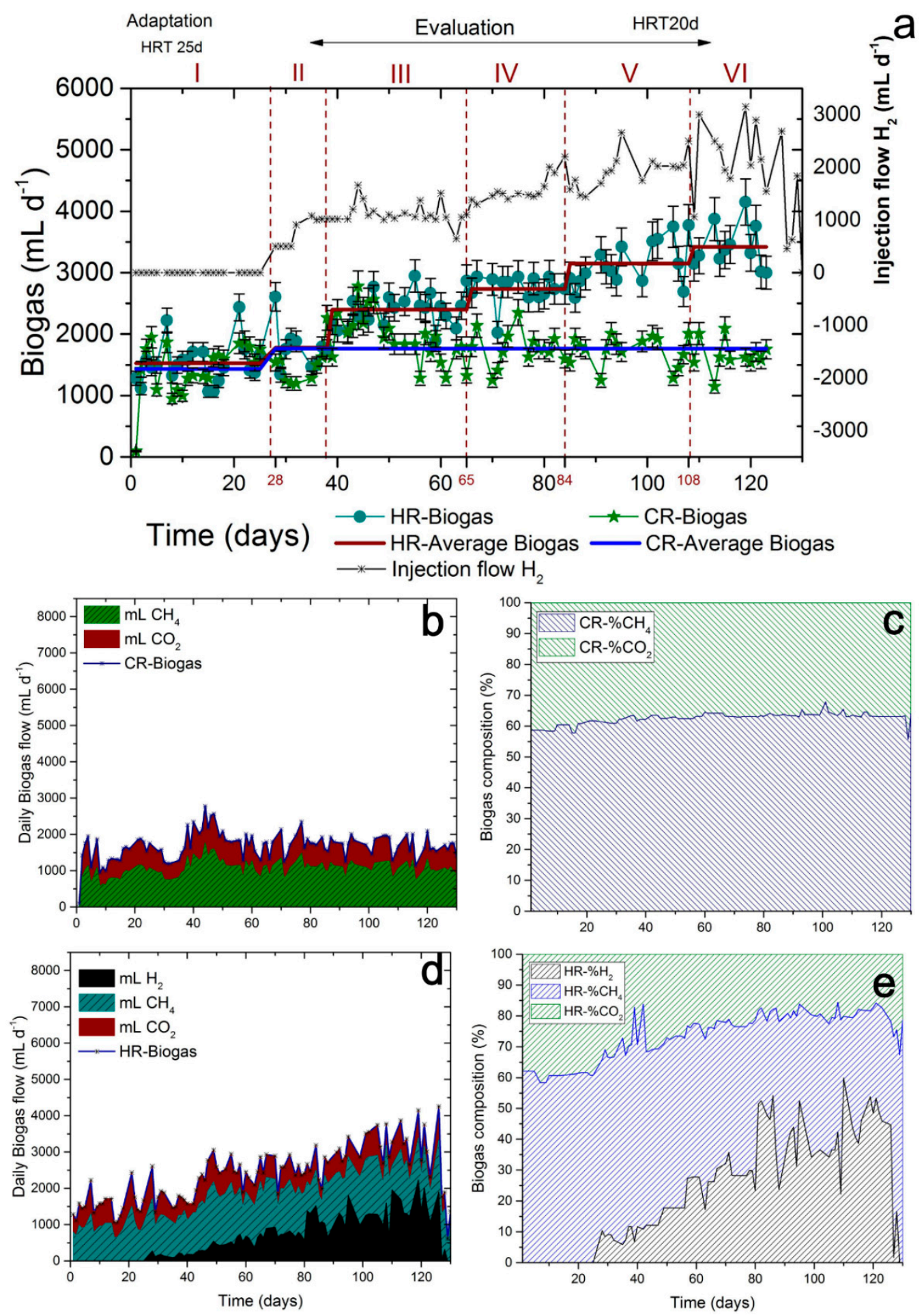

Figure 1. Biogas production and composition in the hydrogen reactor (HR) and control reactor (CR) systems when digesting sewage sludge (SS) under semi-continuous conditions. (a) Biogas production and hydrogen flow injection in the $\mathrm{HR}$ system, (b) daily volumetric flow of $\mathrm{CH}_{4}$ and $\mathrm{CO}_{2}$ in the $\mathrm{CR}$, (c) biogas composition in the $\mathrm{CR}$, (d) daily volumetric flow of $\mathrm{H}_{2}, \mathrm{CH}_{4}$ and $\mathrm{CO}_{2}$ in the $\mathrm{HR}$, (e) biogas composition in the HR.

In the present study, hydrogen flow was added during a single cycle of $6 \mathrm{~h} \mathrm{~d}^{-1}$. The injection velocity for the $6 \mathrm{~h}$ cycle was gradually increased during the evaluation period but did not affect the utilisation of this gas by microorganisms which does not depend on injection velocity. Figure 2 shows that hydrogen output and transfer were proportional to the volume of hydrogen injected. The 
transfer of hydrogen depends only on the properties of the liquid, diffusivity of the gas and biological characteristics of the process [30].

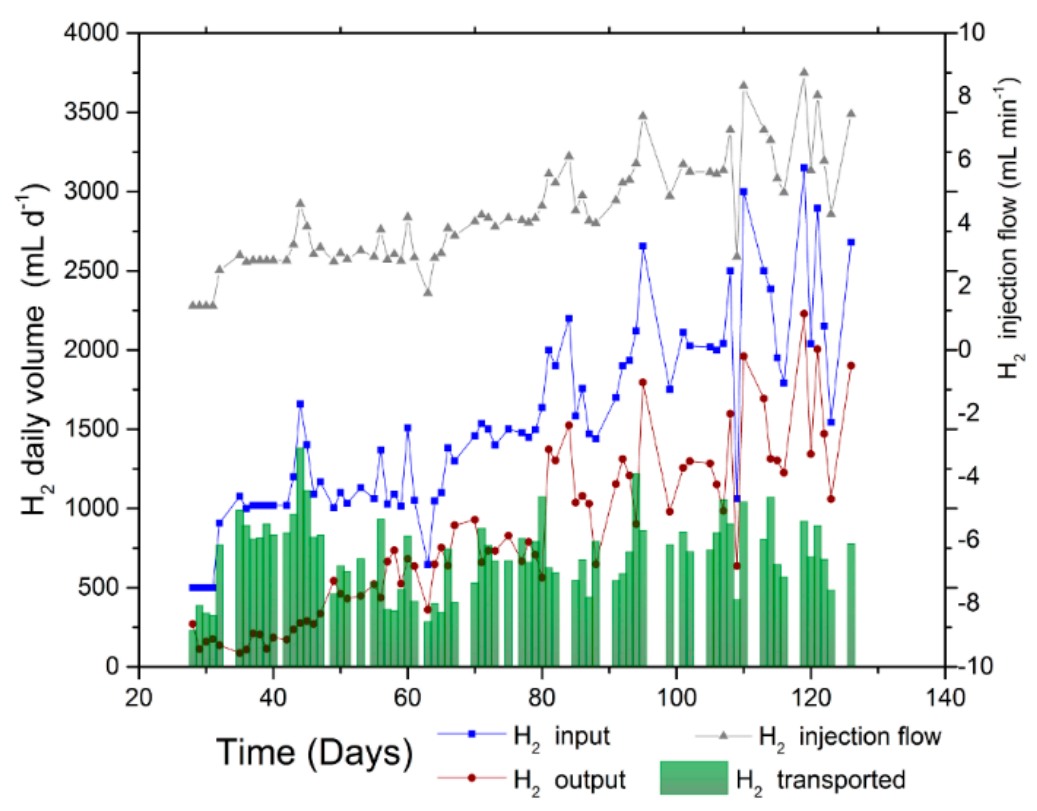

Figure 2. The relation between velocity of hydrogen injection and hydrogen uptake in the HR system.

The results on process performance are shown in Figure 3. The HR showed an increase in total VFA amounts on day 70 onwards (Figure 3a), coinciding with the increase in the average hydrogen injection flow rate from 1125 to $1588 \mathrm{~mL} \mathrm{~d}^{-1}$ and reaching a maximum of $\sim 90 \mathrm{mg} \mathrm{L}^{-1}$ on day 80 . Figure $3 \mathrm{~b}$ indicates that this difference is mainly due to the increase in acetic acid concentration in this reactor. This effect may be associated with changes in microbial populations owing to the greater availability of hydrogen gas. Higher production of acetic acid derives from the conversion of hydrogen in this reactor. This fact would cause an acetic acid build-up unless this event was accompanied by an increase in microbial populations capable of the conversion of this compound into methane. The later decrease in the acetic acid amount may then be associated with the proliferation of acetoclastic methanogens, which prevented a progressive build-up.

The results of monitoring the digestion process did not reveal significant differences in the parameters measured (Figure $3 \mathrm{~d}-\mathrm{f})$. These data revealed similar values $(\mathrm{pH}$, alkalinity and ammonium content) between the two reactors (CR and HR), indicating that the addition of hydrogen did not interfere with assimilation of the carbon source. The removal of VS was on average $54.6 \% \pm 6.1 \%$ for the HR: only slightly higher than that of CR (see Table 2 and Figure 3f, where lower values of VS and TS were detected in the HR system). Therefore, the enhancement of biogas production by this method does not represent any detriment to the digestion performance, nor does it interfere with the stabilisation of the sludge; these properties are a disadvantage observed when readily degradable co-substrates are added for boosting biogas production [27]. 

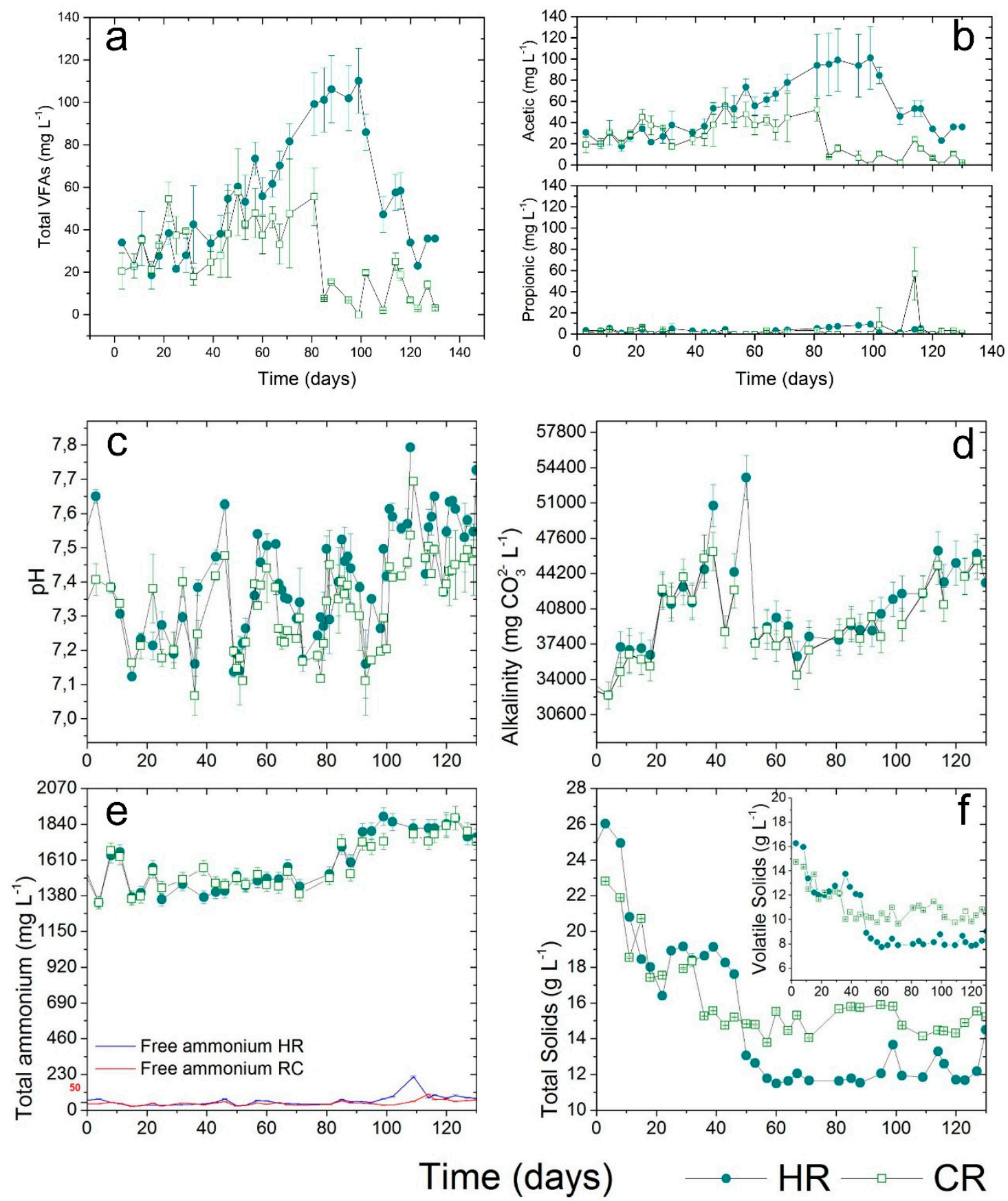

Figure 3. Chemical parameters evaluating the performance of the digestion of SS for the CR and HR. (a) total volatile fatty acids (VFAs), (b) acetic and propionic acids, (c) $\mathrm{pH}$, (d) alkalinity, (e) ammonium and free ammonia, and (f) total solids (TS) and volatile solids (VS).

\subsection{Effect of Hydrogen Addition on Microbial Communities}

Archaeal and Eubacterial community analysis of the samples at the family and genus level are presented in Figure 4a,b and Figure 5a,b respectively (Supplementary Material shows the table with the correspondence family-genus).

The family level of Archaeal community analysis (Figure 4a) indicated that the three predominant groups were Methanoregulaceae and Methanobacteriaceae (both hydrogenotrophic archaea) and Methanosaetaceae, which follows the acetoclastic pathway. These families accounted for $94 \%$ and $88 \%$ of the entire community for SS and inoculum samples, respectively. In SS samples, it is more common to find Methanosaetaceae (45\%) relative to Methanosarcinaceae (2.5\%). Methanosarcinaceae is able 
to maintain both the acetoclastic and hydrogenotrophic pathway and is also easier to find in other substrates like pig slurry.

With respect to the samples obtained from the reactors, no changes were observed in the dominant groups during the adaptation period; however, shifts in the relative abundance of these families emerged due to changes in the dynamics of the reactor (lower HRT) and greater availability of hydrogen for the HR. Figure 4 shows that contrary to what would have been expected [17], acetoclastic methanogens also comprise the majority of methanogens in HR, with Methanosaetaceae being the dominant family. Nonetheless, some hydrogenotrophic methanogens, such as Methanospirillum [31] (belonging to Methanospirillaceae family), increased in abundance during hydrogen addition periods (samples from the HR).
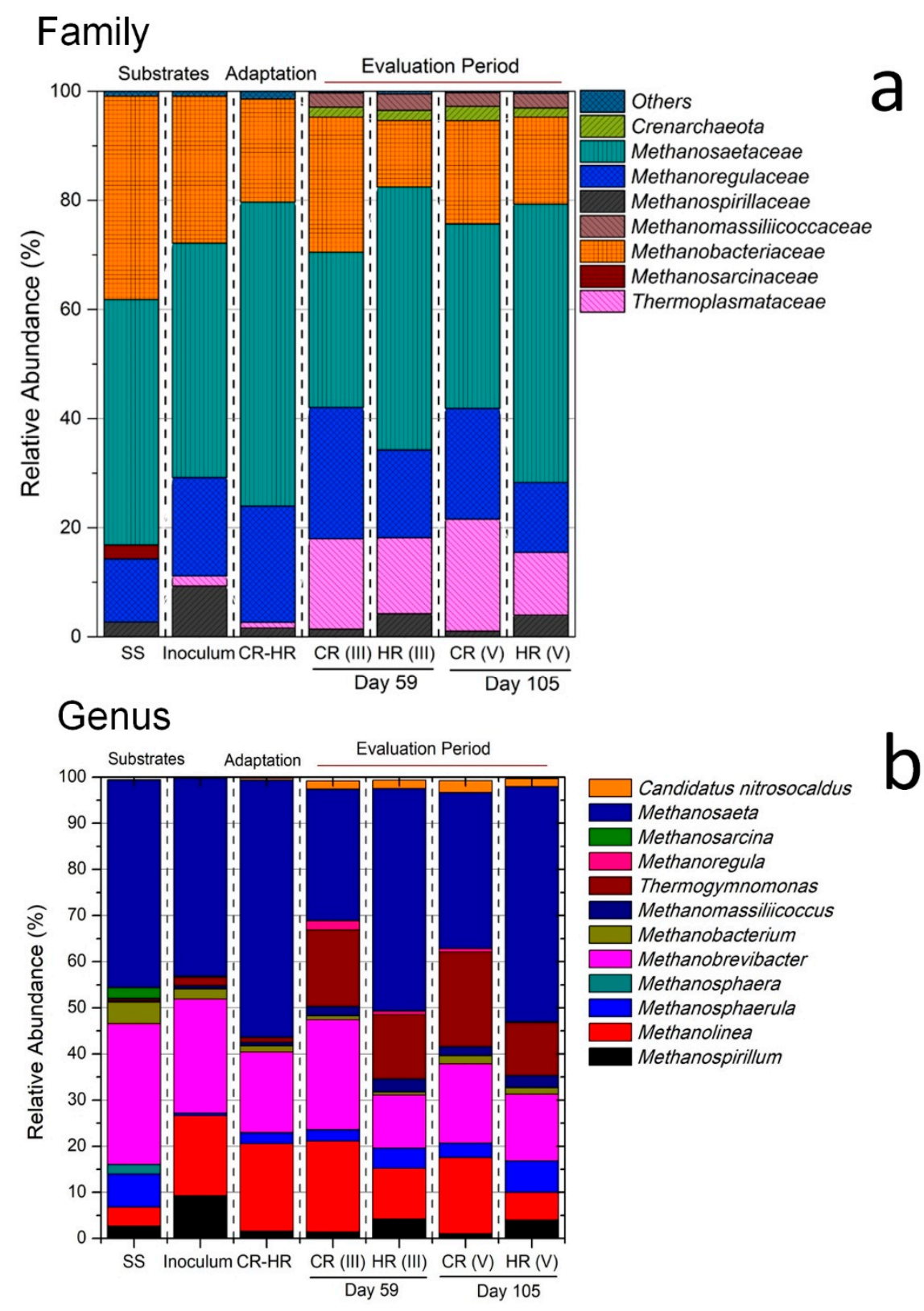

Figure 4. Taxonomic classification of high-throughput sequencing data on the 16S rRNA gene from archaeal communities at a family (a) and genus (b) level. For groups family making up less than $1 \%$ of the total number of sequence reads were classified as 'others'. The genera belonging to the families were identified above $1 \%$. 


\section{Family}

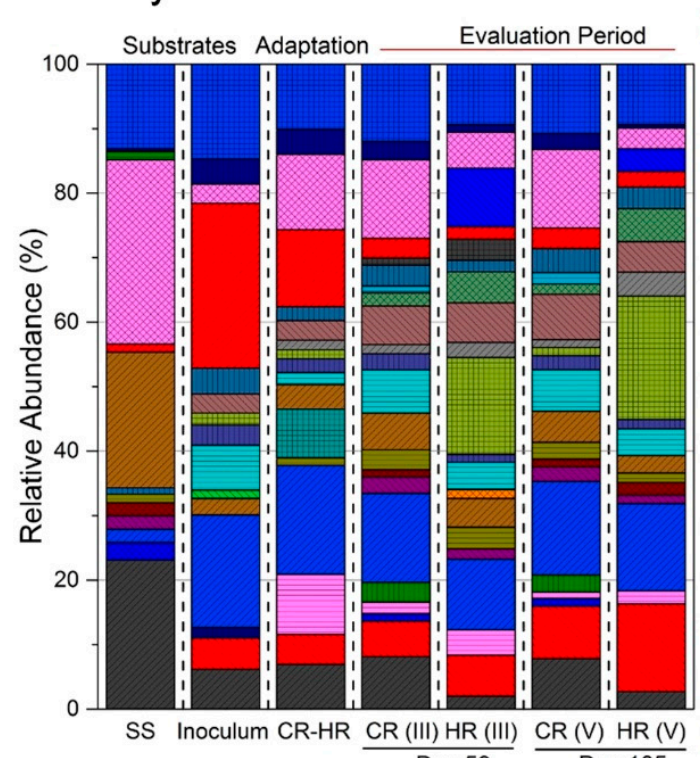

\section{Genus}
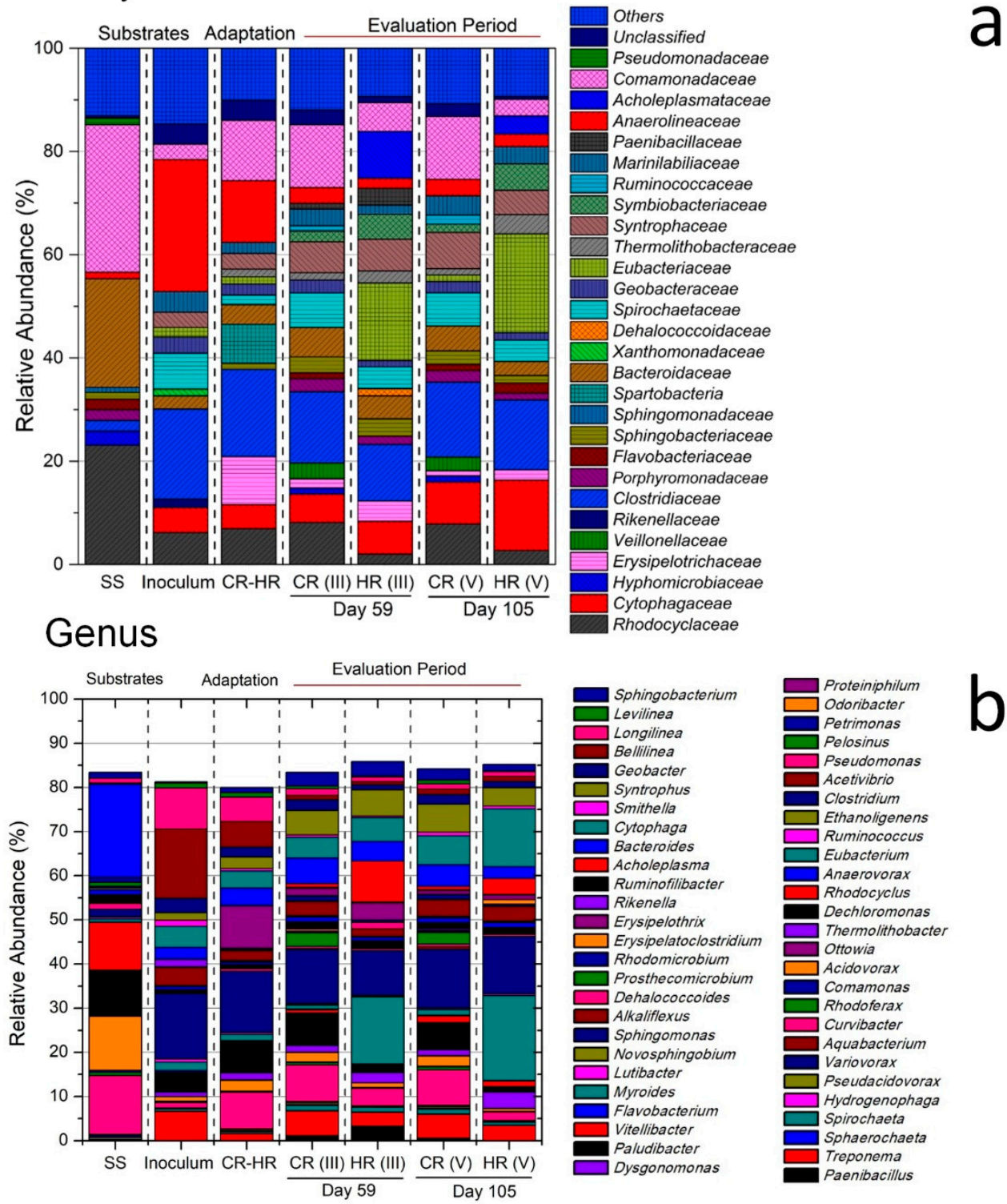

Figure 5. Taxonomic classification of high-throughput sequencing data on $16 S$ rRNA gene from eubacterial communities at family (a) and genus (b) level. For groups family making up less than $1 \%$ of the total number of sequence reads were classified as 'others'. The genera belonging to the families were identified above $1 \%$.

Regarding eubacterial populations, the diversity was much greater for the eubacterial than for archaeal community. Besides, dramatic shifts were observed in the different evaluated samples from $\mathrm{HR}$ and CR, compared to the samples of substrates and adaptation period (Figure 5).

Clear enrichment in homoacetogenic families such as Clostridiaceae and Eubacteriaceae was detected. Figure 5 suggests that Eubacteriaceae was identified in the inoculum at very low relative abundance $(1.8 \%)$, but it reached $\sim 15 \%$ and $19 \%$ in the HR for the samples taken on days 59 and 105 , respectively. Clostridiaceae was also abundant in the inoculum and remained one of the most abundant families throughout the experiment. The sum of the total homoacetogenic bacteria increased from $18 \%$ in the adaptation period to $26 \%$ and $33 \%$ in the HR on days 59 and 106 , respectively. These increments stayed related to the different hydrogen flow rates of 1095 and $1870 \mathrm{~mL} \mathrm{~d}^{-1}$ applied in each case. These eubacterial populations can grow in a $\mathrm{CO}_{2} / \mathrm{H}_{2}$ atmosphere, and therefore had optimal conditions for their growth. 
The enrichment of these homoacetogenic groups along with other acetogenic microorganisms increased the acetate production in HR. This is because these bacteria utilised the hydrogen (transferred from the gas phase) and $\mathrm{CO}_{2}$ to produce acetate, which is subsequently consumed by acetoclastic methanogens (Figure 4). Accordingly, the proliferation of homoacetogenic bacteria in this reactor (HR) could be favouring the proliferation of the acetoclastic Methanosaeta, which follow the acetoclastic route [32]. Microbial analysis supported the hypothesis advanced in the previous section regarding the course of acetic acid content in the HR reactor and explains the higher levels of acetic acid obtained for this system and its posterior decrease as illustrated in Figure $3 \mathrm{~b}$.

Hence, our results allowed us to hypothesise that due to the conditions in the reactors, the pulses of hydrogen chiefly stimulated the enrichment of certain homoacetogenic microbes above the hydrogenotrophic route. Bioaugmentation by $\mathrm{H}_{2}$-producing bacteria has been previously studied for improvement of biogas production and promotion of the hydrogenotrophic pathway [33]. Nevertheless, and contrary to promoting the utilisation of hydrogen and its conversion into methane as expected, the $\mathrm{H}_{2}$-producing bacteria present in the $\mathrm{CR}$ such as Rhodocyclaceae, Syntrophaceae, and Ruminococcaceae decreased in abundance in the HR when hydrogen pulses were added to the reactor. The increase in acetate content in this reactor (as seen in Figure 3b) and results from microbial analysis indicated that this behaviour may probably be associated with the conversion of hydrogen by homoacetogenic bacteria (producing acetate) thus favouring the acetoclastic pathway.

\subsection{Energy Balance}

The main characteristics for the base scenario are presented in Table 3. The volumetric proportion of PS and WAS was 30:70 based on the data reported by the WWTP of the city of León. The energy needs of the WAS system account for $\sim 60 \%$ of the total energy demand of the plant [34]. The chemical oxygen demand (COD) of the wastewater treated in the WAS system was assumed to be $310 \mathrm{mg} \mathrm{L}^{-1}$.

An activated-sludge process requires aeration, which accounts for up to $75 \%$ of the WWTP energy costs, while the treatment and disposal of sludge may be responsible for up to $60 \%$ of the total operational costs [1]. The substitution of the conventional WAS system with a BES leads to a significant decrease in the energy demand. Gil-Carrera and co-workers [35] reported an energy demand of $0.11 \mathrm{~kW} \mathrm{~h} \mathrm{~kg}^{-1}$ COD removed when treating domestic wastewater using a semi-pilot MEC. Heidrich et al. [36] have reported a value of $0.64 \mathrm{~kW} \mathrm{~h} \mathrm{~kg}^{-1}$ COD removed when using a semi-pilot scale microbial cell. These values lead to hypothetical average consumption of $\sim 22 \%$ of the average energy demand reported for conventional WWTPs.

The energy demand of the conventional WWTP was estimated at $938 \mathrm{~kW}$, assuming that $60 \%$ of this value corresponds to the energy needs of the WAS [34], whereas this value decreased to $585 \mathrm{~kW}$ for the alternative proposed. The substitution of the conventional WAS system with a MEC also brings as an advantage the production of hydrogen from conversion of organic matter contained in wastewater. With the hydrogen yield reported by Selembo et al. [37] of $1.87 \mathrm{~m}^{3} \mathrm{H}_{2} \mathrm{~m}^{3}$ reactor ${ }^{-1} \mathrm{~d}^{-1}$, this assumption would translate into an estimate of $185.5 \mathrm{~m}^{3} \mathrm{H}_{2} \mathrm{~h}^{-1}$ from the treatment of wastewater by the BES. This gas is assumed to be subsequently injected into the anaerobic digester. The hydrogen transfer rate calculated from experimental results was $40.4 \mathrm{~mL} \mathrm{H}_{2} \mathrm{~L}^{-1} \mathrm{~h}^{-1}$. Therefore, this figure may lead to the capacity for hydrogen utilisation in a large-scale digester of $178 \mathrm{~m}^{3} \mathrm{H}_{2} \mathrm{~h}^{-1}$, assuming a $10 \%$ enhancement in the gas transfer rate owing to pressure effects in the large-scale system. This value is slightly lower than that of the estimated production of hydrogen by the hypothetical MEC; therefore, a small fraction of hydrogen will not be transformed into methane in this configuration. In addition, a conservative assumption was made, estimating that only $80 \%$ of the hydrogen flow transferred was assimilated by microorganisms [20]. 
Table 3. Main characteristics of the conventional wastewater treatment plant (WWTP) considered (base scenario) and the alternative system (bioelectrochemical systems (BES) unit and $\mathrm{H}_{2}$ conversion).

\begin{tabular}{|c|c|c|}
\hline Parameter & Value & Unit \\
\hline WWTP capacity [38] & 150000 & Eq. Inh. \\
\hline Wastewater quantity & 350 & $\mathrm{~L}$ (Eq. Inh. $)^{-1} \mathrm{~d}^{-1}$ \\
\hline \multicolumn{3}{|c|}{ Characteristics of conventional WWTP (base scenario) } \\
\hline Energy demand WAS [39] & 1.1 & $\mathrm{~kW} \mathrm{~h} \mathrm{~m}^{-3}$ \\
\hline WWTP energy consumption [40] & 1.68 & $\mathrm{~kW} \mathrm{~h}(\mathrm{~kg} \text { COD removed })^{-1}$ \\
\hline Sludge flow & 8.0 & $\mathrm{~m}^{3} \mathrm{~h}^{-1}$ \\
\hline TS & 53.0 & $\mathrm{~g} \mathrm{~L}^{-1}$ \\
\hline$\%$ VS & 73 & $\%$ \\
\hline Digester volume & 4000 & $\mathrm{~m}^{3}$ \\
\hline Electric efficiency CHP unit [41] & 33 & $\%$ \\
\hline Energy production from biogas valorisation by $\mathrm{CHP}$ & 342 & $\mathrm{~kW}$ \\
\hline \multicolumn{3}{|c|}{ BES and $\mathrm{H}_{2}$ conversion during anaerobic digestion } \\
\hline Energy consumption & 0.38 & $\mathrm{kWh}(\mathrm{kg} \text { COD removed })^{-1}$ \\
\hline Secondary sludge production & 2.7 & $\mathrm{~m}^{3} \mathrm{~h}^{-1}$ \\
\hline Sludge flow & 3.8 & $\mathrm{~m}^{3} \mathrm{~h}^{-1}$ \\
\hline Biogas production from $\mathrm{H}_{2}$ conversion (from experimental results) & 0.33 & $\left(\mathrm{~m}^{3}\right.$ biogas $)\left(\mathrm{m}^{3} \mathrm{H}_{2}\right)^{-1}$ \\
\hline Energy production from biogas valorisation by $\mathrm{CHP}$ & 318 & $\mathrm{~kW}$ \\
\hline $\begin{array}{c}\text { Addition of co-substrate: Total energy production from biogas } \\
\text { valorisation by CHP }\end{array}$ & 554 & $\mathrm{~kW}$ \\
\hline
\end{tabular}

The sludge production of the BES configuration was considered to be $25 \%$ of that of the conventional WAS system according to the data reported by Brown et al. [42]. Therefore, the anaerobic digester does not work at full load when the BES is introduced into an existing plant. The energy production thus calculated for the digester was not enough for covering the whole energy demand of the WWTP with the BES configuration; this drawback is due to the lower sludge flow generated by the BES system. Operating the anaerobic digester at full capacity by the addition of a co-substrate with characteristics similar to those of sludge may result in an extra amount of energy, $237 \mathrm{~kW}$, which is still not enough for making this scenario energy self-sufficient. A co-substrate with specific methane production of $\sim 400 \mathrm{~mL} \mathrm{CH}_{4} \mathrm{~g} \mathrm{VS}^{-1}$ would be necessary (considering similar VS content) for covering all the energy needs of the WWTP when BES is chosen as an alternative. Suitable co-substrates may be those with high organic content of readily degradable materials as glycerol, cheese whey, food wastes [43-45] or those with high lipid and protein contents [46].

This study only takes into account energy facts, to make an initial approximation to the feasibility of integrating a BES as alternative to the conventional activated sludge systems. However, it must be borne in mind that at the current state of the art the capital investment required is too high to materialise this concept. Escapa et al. [47] speculated that if large-scale BES implementation is to become a reality, the feasibility of using this technology is closely dependent on the improvement attained in cathode performance coupled to the use of low-cost cathode materials, approximating the threshold price for investment cost to $1200 € \mathrm{~m}^{-3}$ of anodic chamber.

\section{Conclusions}

The benefit of hydrogen addition to the digestion of sludge was associated with the increase in biogas production owing to the conversion of hydrogen into acetate and subsequent transformation into methane. This process did not lead to a high enrichment in the composition of biogas produced, but on the contrary, significantly increased the productivity of the digester in terms of the volumetric gas production rate. This finding is explained by the fact that the hydrogenotrophic pathway was not favoured in spite of the injection of hydrogen. The uptake of hydrogen was carried out to a great extent by the eubacterial community, thereby promoting the enrichment of acetoclastic methanogens. The addition of hydrogen did not worsen the stabilisation of sludge, with the reactor yielding values 
of VS removal similar to those of the CR, which was intended to evaluate the digestion of sludge as a sole substrate.

The presence of hydrogen gas promoted a shift in eubacterial populations, specifically towards homoacetogenic bacteria, which increased the production of acetate. This change in turn favoured the enrichment of the acetoclastic methanogen family Methanosaetaceae, which was already identified in high abundance in the inoculum and fresh sludge, therefore avoiding an acetic acid build-up.

The substitution of a conventional WAS system by a BES leads to a significant reduction in energy demands, but this approach itself does not guarantee the energy self-sufficient status. The lower availability of organic matter to the anaerobic digester results in lower energy production becoming another challenge for this type of technology in addition to the well-known price constraint. Unless a reduction in energy consumption is attempted via an increase in the efficiency of various pieces of equipment at the WWTP or via an increase in biogas production by means of an extra co-substrate, energy self-sufficiency may not be possible with the proposed approach.

Supplementary Materials: The following are available online at http:/ /www.mdpi.com/1996-1073/12/7/1228/ s1. Supplementary data about Tables S1 and S2 are shown in the supplementary file.

Author Contributions: Conceptualization and supervision, X.G.; methodology, software and formal analysis, E.J.M., C.B.A. and A.S.; investigation, X.G. and E.J.M.; data curation, D.B. and O.M.; Writing-Original Draft preparation, E.J.M., C.B.A. and A.S.; Writing-Review and Editing, X.G.; project administration and funding acquisition, X.G.

Funding: This research was possible thanks to financial support from Ministerio de Economía y Competitividad and ERDF through project CTQ2015-68925-R, UNLE15-EE-3070 and 'Junta de Castilla y Leon' project LE060U16. Ana Sotres thanks the regional 'Junta de Castilla y León' for the postdoctoral contract associated with project ref: LE060U16 co-financed by FEDER funds.

Acknowledgments: Authors wish to thank WWTP of León for providing samples and facilitating the execution of the research work.

Conflicts of Interest: The authors declare no conflict of interest.

\section{References}

1. Gude, V.G. Wastewater treatment in microbial fuel cells-An overview. J. Clean. Prod. 2016, 122, $287-307$. [CrossRef]

2. Wacławek, S.; Grübel, K.; Silvestri, D.; Padil, V.V.; Wacławek, M.; Černík, M.; Varma, S.R. Disintegration of Wastewater Activated Sludge (WAS) for Improved Biogas Production. Energies 2018, 12, 21. [CrossRef]

3. Hosseini Koupaie, E.; Johnson, T.; Eskicioglu, C. Comparison of Different Electricity-Based Thermal Pretreatment Methods for Enhanced Bioenergy Production from Municipal Sludge. Molecules 2018, 23, 2006. [CrossRef]

4. Martínez, E.J.; Rosas, J.G.; Morán, A.; Gómez, X. Effect of ultrasound pretreatment on sludge digestion and dewatering characteristics: Application of particle size analysis. Water 2015, 7, 6483-6495. [CrossRef]

5. Xia, Y.; Yang, C.; Zhang, T. Microbial effects of part-stream low-frequency ultrasonic pretreatment on sludge anaerobic digestion as revealed by high-throughput sequencing-based metagenomics and metatranscriptomics. Biotechnol. Biofuels 2018, 11, 47. [CrossRef] [PubMed]

6. González, J.; Sánchez, E.M.; Gómez, X. Enhancing Anaerobic Digestion: The Effect of Carbon Conductive Materials. C 2018, 4, 59. [CrossRef]

7. Keucken, A.; Habagil, M.; Batstone, D.; Jeppsson, U.; Arnell, M. Anaerobic Co-Digestion of Sludge and Organic Food Waste-Performance, Inhibition, and Impact on the Microbial Community. Energies 2018, 11, 2325. [CrossRef]

8. Martínez, E.J.; Gil, M.V.; Fernandez, C.; Rosas, J.G.; Gómez, X. Anaerobic codigestion of sludge: Addition of butcher's fat waste as a cosubstrate for increasing biogas production. PLoS ONE 2016, 11, e0353139. [CrossRef]

9. Al bkoor Alrawashdeh, K.; Pugliese, A.; Slopiecka, K.; Pistolesi, V.; Massoli, S.; Bartocci, P.; Bidini, G.; Fantozzi, F. Codigestion of Untreated and Treated Sewage Sludge with the Organic Fraction of Municipal Solid Wastes. Fermentation 2017, 3, 35. [CrossRef] 
10. Zinder, S.H. Microbiology of anaerobic conversion of organic wastes to methane: Recent developments. Am. Soc. Microbiol. News 1984, 50, 294-298.

11. Demirel, B.; Scherer, P. The roles of acetotrophic and hydrogenotrophic methanogens during anaerobic conversion of biomass to methane: A review. Rev. Environ. Sci. Bio/Technology 2008, 7, 173-190. [CrossRef]

12. Thauer, R.K.; Kaster, A.-K.; Seedorf, H.; Buckel, W.; Hedderich, R. Methanogenic archaea: Ecologically relevant differences in energy conservation. Nat. Rev. Microbiol. 2008, 6, 579. [CrossRef] [PubMed]

13. Holmes, D.E.; Smith, J.A. Biologically Produced Methane as a Renewable Energy Source. Adv. Appl. Microbiol. 2016, 97, 1-61. [PubMed]

14. Cayol, J.-L.; Fardeau, M.-L.; Garcia, J.-L.; Ollivier, B. Evidence of interspecies hydrogen transfer from glycerol in saline environments. Extremophiles 2002, 6, 131-134. [CrossRef] [PubMed]

15. Bagi, Z.; Ács, N.; Bálint, B.; Horváth, L.; Dobó, K.; Perei, K.R.; Rákhely, G.; Kovács, K.L. Biotechnological intensification of biogas production. Appl. Microbiol. Biotechnol. 2007, 76, 473-482. [CrossRef]

16. Nzila, A. Mini review: Update on bioaugmentation in anaerobic processes for biogas production. Anaerobe 2017, 46, 3-12. [CrossRef] [PubMed]

17. Luo, G.; Angelidaki, I. Co-digestion of manure and whey for in situ biogas upgrading by the addition of H2: Process performance and microbial insights. Appl. Microbiol. Biotechnol. 2013, 97, 1373-1381. [CrossRef] [PubMed]

18. Luo, G.; Angelidaki, I. Integrated biogas upgrading and hydrogen utilization in an anaerobic reactor containing enriched hydrogenotrophic methanogenic culture. Biotechnol. Bioeng. 2012, 109, 2729-2736. [CrossRef]

19. Luo, G.; Angelidaki, I. Hollow fiber membrane based H2 diffusion for efficient in situ biogas upgrading in an anaerobic reactor. Appl. Microbiol. Biotechnol. 2013, 97, 3739-3744. [CrossRef] [PubMed]

20. Luo, G.; Johansson, S.; Boe, K.; Xie, L.; Zhou, Q.; Angelidaki, I. Simultaneous hydrogen utilization and in situ biogas upgrading in an anaerobic reactor. Biotechnol. Bioeng. 2012, 109, 1088-1094. [CrossRef]

21. McCarty, P.L.; Bae, J.; Kim, J. Domestic wastewater treatment as a net energy producer-Can this be achieved? Environ. Sci. Technol. 2011, 45, 7100-7106. [CrossRef] [PubMed]

22. Escapa, A.; Mateos, R.; Martínez, E.J.; Blanes, J. Microbial electrolysis cells: An emerging technology for wastewater treatment and energy recovery. from laboratory to pilot plant and beyond. Renew. Sustain. Energy Rev. 2016, 55, 942-956. [CrossRef]

23. Stoll, A.Z.; Dolfing, J.; Xu, P. Minimum Performance Requirements for Microbial Fuel Cells to Achieve Energy-Neutral Wastewater Treatment. Water 2018, 10, 243. [CrossRef]

24. Pant, D.; Singh, A.; Van Bogaert, G.; Irving Olsen, S.; Singh Nigam, P.; Diels, L.; Vanbroekhoven, K. Bioelectrochemical systems (BES) for sustainable energy production and product recovery from organic wastes and industrial wastewaters. RSC Adv. 2012, 2, 1248-1263. [CrossRef]

25. APHA. Standard Methods for the Examination of Water and Wastewater; APHA: Washington, DC, USA, 2005; ISBN 9780875530475.

26. Walkley, A.; Black, I.A. An examination of the Degtjareff method for determining soil organic matter, and a proposed modification of the chromic acid titration method. Soil Sci. 1934, 37, 29-38. [CrossRef]

27. Fierro, J.; Martinez, E.J.; Rosas, J.G.; Fernández, R.A.; López, R.; Gomez, X. Co-Digestion of Swine Manure and Crude Glycerine: Increasing Glycerine Ratio Results in Preferential Degradation of Labile Compounds. Water. Air. Soil Pollut. 2016, 227. [CrossRef]

28. Callaway, T.R.; Dowd, S.E.; Wolcott, R.D.; Sun, Y.; McReynolds, J.L.; Edrington, T.S.; Byrd, J.A.; Anderson, R.C.; Krueger, N.; Nisbet, D.J. Evaluation of the bacterial diversity in cecal contents of laying hens fed various molting diets by using bacterial tag-encoded FLX amplicon pyrosequencing. Poult. Sci. 2009, 88, 298-302. [CrossRef]

29. Takai, K.E.N. Rapid Detection and Quantification of Members of the Archaeal Community by Quantitative PCR Using Fluorogenic Probes. Appl. Environ. Microbiol. 2000, 66, 5066-5072. [CrossRef]

30. Bensmann, A.; Hanke-Rauschenbach, R.; Heyer, R.; Kohrs, F.; Benndorf, D.; Reichl, U.; Sundmacher, K. Biological methanation of hydrogen within biogas plants: A model-based feasibility study. Appl. Energy 2014, 134, 413-425. [CrossRef]

31. Demirel, B. Major pathway of methane formation from energy crops in agricultural biogas digesters. Crit. Rev. Environ. Sci. Technol. 2014, 44, 199-222. [CrossRef] 
32. Karakashev, D.; Batstone, D.J.; Trably, E.; Angelidaki, I. Acetate Oxidation Is the Dominant Methanogenic Pathway from Acetate in the Absence of Methanosaetaceae. Appl. Environ. Microbiol. 2006, 72, 5138-5141. [CrossRef]

33. Ács, N.; Bagi, Z.; Rákhely, G.; Minárovics, J.; Nagy, K.; Kovács, K.L. Bioaugmentation of biogas production by a hydrogen-producing bacterium. Bioresour. Technol. 2015, 186, 286-293. [CrossRef] [PubMed]

34. Gu, Y.; Li, Y.; Li, X.; Luo, P.; Wang, H.; Wang, X.; Wu, J.; Li, F. Energy Self-sufficient Wastewater Treatment Plants: Feasibilities and Challenges. Energy Procedia 2017, 105, 3741-3751. [CrossRef]

35. Gil-Carrera, L.; Escapa, A.; Carracedo, B.; Morán, A.; Gómez, X. Performance of a semi-pilot tubular microbial electrolysis cell (MEC) under several hydraulic retention times and applied voltages. Bioresour. Technol. 2013, 146, 63-69. [CrossRef] [PubMed]

36. Heidrich, E.S.; Dolfing, J.; Scott, K.; Edwards, S.R.; Jones, C.; Curtis, T.P. Production of hydrogen from domestic wastewater in a pilot-scale microbial electrolysis cell. Appl. Microbiol. Biotechnol. 2013, 97, 6979-6989. [CrossRef] [PubMed]

37. Selembo, P.A.; Perez, J.M.; Lloyd, W.A.; Logan, B.E. High hydrogen production from glycerol or glucose by electrohydrogenesis using microbial electrolysis cells. Int. J. Hydrogen Energy 2009, 34, 5373-5381. [CrossRef]

38. Houillon, G.; Jolliet, O. Life cycle assessment of processes for the treatment of wastewater urban sludge: Energy and global warming analysis. J. Clean. Prod. 2005, 13, 287-299. [CrossRef]

39. Mizuta, K.; Shimada, M. Benchmarking energy consumption in municipal wastewater treatment plants in Japan. Water Sci. Technol. 2010, 62, 2256-2262. [CrossRef]

40. Hernández-Sancho, F.; Molinos-Senante, M.; Sala-Garrido, R. Energy efficiency in Spanish wastewater treatment plants: A non-radial DEA approach. Sci. Total Environ. 2011, 409, 2693-2699. [CrossRef]

41. Pöschl, M.; Ward, S.; Owende, P. Evaluation of energy efficiency of various biogas production and utilization pathways. Appl. Energy 2010, 87, 3305-3321. [CrossRef]

42. Brown, R.K.; Harnisch, F.; Dockhorn, T.; Schröder, U. Examining sludge production in bioelectrochemical systems treating domestic wastewater. Bioresour. Technol. 2015, 198, 913-917. [CrossRef] [PubMed]

43. Menon, A.; Ren, F.; Wang, J.Y.; Giannis, A. Effect of pretreatment techniques on food waste solubilization and biogas production during thermophilic batch anaerobic digestion. J. Mater. Cycles Waste Manag. 2016, 18, 222-230. [CrossRef]

44. Escalante, H.; Castro, L.; Amaya, M.P.; Jaimes, L.; Jaimes-Estévez, J. Anaerobic digestion of cheese whey: Energetic and nutritional potential for the dairy sector in developing countries. Waste Manag. 2018, 71, 711-718. [CrossRef] [PubMed]

45. González, R.; Smith, R.; Blanco, D.; Fierro, J.; Gómez, X. Application of thermal analysis for evaluating the effect of glycerine addition on the digestion of swine manure. J. Therm. Anal. Calorim. 2019, 135, 2277-2286. [CrossRef]

46. Angelidaki, I.; Ellegaard, L. Codigestion of manure and organic wastes in centralized biogas plants. Appl. Microbiol. Biotechnol. 2003, 109, 95-105.

47. Escapa, A.; Gómez, X.; Tartakovsky, B.; Morán, A. Estimating microbial electrolysis cell (MEC) investment costs in wastewater treatment plants: Case study. Int. J. Hydrogen Energy 2012, 37, 18641-18653. [CrossRef]

(C) 2019 by the authors. Licensee MDPI, Basel, Switzerland. This article is an open access article distributed under the terms and conditions of the Creative Commons Attribution (CC BY) license (http://creativecommons.org/licenses/by/4.0/). 